\title{
MEMBANGUN LEARNING ORGANIZATION DI SAMUDERA INDONESIA GROUP (SIG)
}

\author{
Anglena Dhonna Offia \\ Program Studi S2 MM Wijawiyata Manajemen \\ Sekolah Tinggi Manajemen PPM \\ Yanet Molina \\ Program Studi S2 MM Wijawiyata Manajemen \\ Sekolah Tinggi Manajemen PPM
}

Ruang lingkup Learning Organization (LO) adalah pembelajaran individual, tim, hingga organisasi dimana individu memiliki kesadaran untuk belajar, individu dalam tim pun aktif melakukan kegiatan yang berkaitan dengan pembelajaran, dan organisasi sebagai fasilitator dan senantiasa mendukung kegiatan tersebut. Penelitian tesis ini menganalisa sejauhmana LO di SIG dengan pemaparan berdasarkan 5 (lima) sub sistem, dinamika pembelajaran, pemberdayaan manusia, pengelolaan pengetahuan, teknologi, dan organisasi. Metode wawancara mendalam dan Focus Group Discussion (FGD) digunakan sebagai metodologi untuk melakukan analisis dan dasar pembuatan implementasi membangun LO. Berdasarkan hasil wawancara, FGD, dan observasi aktivitas pembelajaran ini belum berjalan dengan baik, karena arus informasi dan kegiatan pembelajaran belum merata di setiap level dan bisnis unit atau anak perusahaan. 


\section{PENDAHULUAN}

Situasi persaingan bisnis yang semakin dinamis, memicu perubahan pada karakteristik lingkungan kerja, baik dari sisi strategi organisasi, karyawan, dan sumber daya lainnya. Penerapan LO, memberikan tantangan bagi organisasi tidak hanya membenahi infrastruktur, tetapi juga mampu mendorong tumbuhnya budaya belajar sampai ke tingkat individu. Pada masa mendatang kemampuan organisasi untuk berubah dan belajar secara berkesinambungan dapat menjadi modal atau value added bagi organisasi agar dapat memenangkan persaingan. Pandangan ini yang kemudian ditangkap oleh Samudera Indonesia Group (SIG), bahwa dengan menjadikan sebuah organisasi pembelajar serta memandang bahwa perubahan sebagai peluang yang positif dalam berkreasi dan belajar akan memberikan kontribusi positif bagi SIG di masa depan.

Sebagai organisasi yang bergerak dibidang jasa transportasi dan logistik yang tertua di Indonesia, perlu disadari bahwa kelanggengan suatu organisasi tidak terjaga bilamana organisasi tidak melakukan proses belajar yang berkelanjutan, inovasi serta proses adaptasi. Saat ini SIG memang menyampaikan keinginannya untuk menerapkan konsep LO, infrastruktur sedang dibangun, yakni dengan mencoba membangun konsep e-learning. Walaupun demikian, tidak memadai apabila hanya fokus pada infrastruktur saja, tetapi perlu diperhatikan bagaimana kesiapan karyawan untuk menjadi individu pembelajar yang aktif, terkait dengan hal tersebut membimbing individu yang diharapkan merupakan tantangan bagi SIG, sebab terdapat indikasi hambatan terlihat dari tidak berjalannya proses sharing knowledge setelah seorang karyawan mengikuti pelatihan atau training. Secara umum, terdapat kebijakan yang mengatur kewajiban seseorang untuk melakukan sharing knowledge. Pada awal penerapan kebijakan, proses berjalan dengan baik, namun sejalan dengan waktu, proses tersebut tidak berjalan sebagaimana mestinya. Disamping itu kebutuhan terhadap LO didasarkan akan keinginan meningkatkan performa organisasi, meningkatkan kualitas, untuk mewujudkan keunggulan kompetitif serta untuk menangani perubahan.

\subsection{Rumusan Masalah}

Berdasarkan latar belakang masalah yang telah dipaparkan sebelumnya mengenai penerapan LO di SIG, maka permasalahan utama yang akan diteliti pada tesis ini adalah "Sejauhmana penerapan Learning Organization di SIG yang dikaji berdasarkan model sistem LO Marquardt?”

\subsection{Ruang Lingkup}

Ruang lingkup penulisan tesis ini mengambil obyek Samudera Indonesia Group (SIG) dengan dibatasi pada wilayah di Jakarta.

\subsection{Pembatasan Masalah}

Peneliti membatasi penelitian pada permasalahan lima subsistem Learning Organization, yakni learning, knowledge, people, organization, dan technology, tidak meliputi aspek knowledge management dan organizational learning.

\section{TINJAUAN PUSTAKA}

Dalam rangka melakukan identifikasi Learning Organization di SIG diperlukan beberapa teori yang menjadi dasar pemahaman proses pengidentifikasian. Pada bab ini dibahas lebih lanjut landasan teori yang digunakan sebagai pedoman penelitian, meliputi pengertian, karakteristik, 
kerangka konseptual, sintesis teori, dan perspektif penelitian yang relevan.

\subsection{Pengertian Learning Organization (LO)}

Banyak pandangan dari sejumlah ahli mengenai pengertian LO, hal ini terjadi karena LO telah banyak berkembang dan diterapkan sebagai salah satu strategi organisasi atau organisasi untuk menjawab tantangan dalam dunia bisnis baik dalam maupun luar negeri. Senge (1994) mendefinisikan bahwa LO "...where people continually expand their capacity to create the results they truly desire, where new and expansive patterns of thinking are nurtured, where collective is set free, and where people are continually learning how to learn together".

Sebagian besar teori tentang LO lebih menekankan pada proses diterimanya suatu pengetahuan dan ide yang secara proaktif dilakukan oleh seluruh individu dalam organisasi, dimana individu-individu tersebut menjadi suatu kelompok yang memperluas kapasitasnya secara terus menerus untuk mencapai suatu hasil yang diinginkan dan pola berpikir baru yang dikembangkan. Organisasi menyediakan waktu dan tempat kepada individu dan kelompok untuk mengeluarkan aspirasi dan bertukar informasi serta memberikan kebebasan kepada aspirasi individu dan kelompok untuk belajar sehingga memungkinkan terjadinya peningkatan kemampuan dalam mengubah informasi yang diperolehnya menjadi suatu pengetahuan yang berharga, yang dapat meningkatkan kemampuan adaptasi organisasi dimasa yang akan datang.

\subsection{Model Learning Organization}

Marquardt dalam Building The Learning Organization menjelaskan bahwa dalam sistem LO terdapat 5 subsistem yang saling berkaitan (Gambar 1.). Subsistem tersebut antara lain adalah: pembelajaran, organisasi, pengetahuan, manusia dan teknologi, dan didalam subsistem tersebut masih terdapat kajian yang membahas detail dari tema subsistem LO.

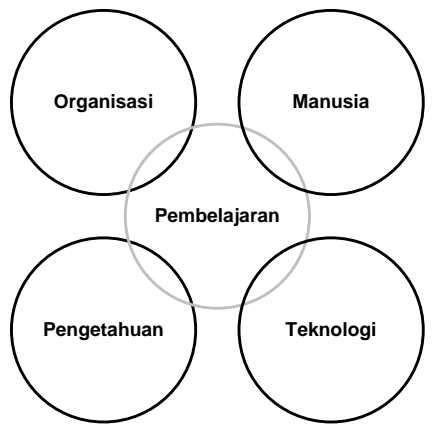

Gambar 1.

Model Sistem LO

\subsection{Sistesis Teori}

Untuk melakukan identifikasi penerapan LO pada SIG, akan digunakan konsep Marquardt, yakni dengan konsep yang komprehensif dimana LO dibangun dengan 5 subsistem yang saling berkaitan. Subsistem tersebut terdiri dari: Organisasi, manusia, pengetahuan, teknologi dan pembelajaran. Selain itu dalam masing- 
masing subsistem tersebut masih terdapat subsistem yang lebih kecil.

Untuk melihat sejauh mana penerapan LO dalam organisasi digunakan alat assesment berupa The Learning Organization Profile (LOP) yang diadaptasi dari Marquardt (2002) dalam mengidentifikasi profil LO organisasi. LOP terdiri dari 10 pertanyaan yang mewakili 5 subsistem dalam System Learning Organization Model serta juga mewakili pernyataan-pernyataan yang berhubungan dengan individu, tim dan organisasi. LOP sudah sering digunakan di berbagai macam organisasi, termasuk didalamnya organisasi transportasi.

Konsep kuesioner Marquardt ini dapat dikatakan sederhana dan cukup sesuai untuk organisasi SIG (berdasarkan hasil diskusi dengan pihak CHR), adapun dalam pelaksanaannya apabila ada yang ingin digali lebih dalam dapat dilakukan panduan wawancara berdasarkan konsep dari ahli lain yang dinilai tepat. LOP ini digunakan sebagai panduan wawancara, dimana tools tersebut sudah pernah dilakukan di Indonesia pada penelitian Edi Purwanto mengenai penerapan LO pada Dirjen Perlindungan HAM tahun 2003.

\subsection{Perspektif Penelitian Yang Relevan \\ Kajian-kajian terdahulu mengenai} Membangun LO dan Penerapan LO dapat dibedakan berdasarkan aspek kajian dan metode penelitiannya, sebagaimana yang terangkum pada Tabel 1. dibawah ini:

Tabel 1.

Kajian Penelitian Terdahulu Mengenai Penerapan LO

\begin{tabular}{|c|c|c|c|c|}
\hline No & $\begin{array}{c}\text { Fokus Penelitian dan } \\
\text { Referensi }\end{array}$ & Aspek Kajian & Metode Penelitian & Temuan \\
\hline 1 & $\begin{array}{l}\text { Examining the } \\
\text { relationship between } \\
\text { Learning organization } \\
\text { dimensions and change } \\
\text { adaption, innovation as } \\
\text { well as organizational } \\
\text { performance (Awbrey, } \\
\text { S.) }\end{array}$ & $\begin{array}{l}\text { Hubungan perubahan, } \\
\text { inovasi dan Dimensi } \\
\text { LO: (Learning } \\
\text { transfer climate, } \\
\text { information sharing } \\
\text { and management } \\
\text { practices, risk taking } \\
\text { promotion and } \\
\text { reinforcement, high } \\
\text { performance team } \\
\text { environment and } \\
\text { knowledge } \\
\text { management) }\end{array}$ & $\begin{array}{l}\text { Kuesioner dengan } 109 \text { butir } \\
\text { pernyataan. Jumlah sampel: } \\
\text { - } 300 \text { orang karyawan } \\
\text { departemen IT } \\
\text { - } 256 \text { orang karyawan } \\
\text { divisi large health care } \\
\text { insurance organization } \\
\text { - } 189 \text { orang karyawan } \\
\text { bagian manufaktur } \\
\text { - } 60 \text { karyawan bagian } \\
\text { manufaktur dari } \\
\text { organisasi berbeda. }\end{array}$ & $\begin{array}{l}\text { Dimensi LO yang } \\
\text { terpenting untuk } \\
\text { adaptasi } \\
\text { perubahan, } \\
\text { pengenalan } \\
\text { service dan } \\
\text { produk, performa } \\
\text { organisasi } \\
\text { berkaitan dengan } \\
\text { struktur, budaya } \\
\text { dan sistem } \\
\text { informasi }\end{array}$ \\
\hline 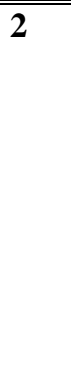 & $\begin{array}{l}\text { The Learning } \\
\text { Organization Model } \\
\text { across Vocational and } \\
\text { Academic } \\
\text { Teacher Groups (Park, } \\
\text { J., 2006) }\end{array}$ & $\begin{array}{l}\text { Multiple group } \\
\text { confirmatory factor } \\
\text { analysis digunakan } \\
\text { untuk menyelidiki } \\
\text { faktor } \\
\text { invarian antara } \\
\text { kelompok-kelompok } \\
\text { guru kejuruan dan } \\
\text { akademis pada ukuran }\end{array}$ & $\begin{array}{l}\text { The Learning Organization } \\
\text { Questionnaire for Schools } \\
\text { (Park, 2006) dengan } 35 \\
\text { item pernyataan } \\
\text { Sampel: } \\
\text { - } 488 \text { guru sekolah } \\
\quad \text { menengah vokasional } \\
\quad \text { yang dipekerjakan oleh } \\
\text { kota dan propinsi }\end{array}$ & $\begin{array}{l}\text { Lima disiplin } \\
\text { Senge (1990) } \\
\text { dapat } \\
\text { dioperasionalkan } \\
\text { dan sama } \\
\text { diterapkan dalam } \\
\text { dua kelompok } \\
\text { guru yang berbeda } \\
\text { di }\end{array}$ \\
\hline
\end{tabular}




\begin{tabular}{||l||l||l||l||}
\hline \hline & konsep LO & $\begin{array}{l}\text { Kantor Pendidikan } \\
\text { selama tahun akademik } \\
2005-2006\end{array}$ \\
& & & Korea \\
\hline
\end{tabular}

\section{KERANGKA ANALISIS}

\subsection{Metode Penelitian}

Penelitian ini menggunakan pendekatan kualitatif. Secara garis besar penelitian kualitatif mempunyai karakteristik yaitu pemahaman mendalam, karena mempertanyakan makna suatu obyek secara mendalam dan tuntas pemahaman mendalam, karena mempertanyakan makna suatu obyek secara mendalam dan tuntas.

Pendekatan kualitatif merupakan suatu proses memahami masalah sosial atau manusia, mendasarkan pada suatu gambaran holistik, kompleks, diolah dengan kata-kata, menyampaikan pandangan detail pada informan dan dilakukan dalam kondisi yang alami.

\subsection{Batasan Konteks Penelitian}

Seperti telah diutarakan di atas bahwa permasalahan dalam penelitian ini adalah proses transfer pengetahuan antar karyawan di SIG Jakarta. Memperhatikan karakteristik penelitian kualitatif di atas dan untuk menyelesaikan masalah penelitian, maka lingkup konteks bidang studi penelitian ini adalah "Learning Organization atau LO" tanpa membahas secara rinci knowledge management dan organizational learning dengan lokasi penelitian pada SIG, Jakarta.

Adapun penentuan obyek penelitian organisasi tersebut diatas, ditetapkan dengan kriteria-kriteria sebagai berikut. Pertama, level karyawan dibagi menjadi 2 level, level manajerial adalah golongan 6-8, sedangkan level non manajerial adalah golongan 3-5, SIG sendiri dapat dibagi menjadi 4 lini bisnis, oleh karena itu dipilih subyek yang mewakili kedua kategori tersebut, level karyawan dan lini bisnis. Kedua, karyawan yang menjadi subyek adalah mereka yang telah bekerja minimal 9 tahun masa kerja. Ketiga, karyawan organisasi yang dipilih oleh counterpart (Kepala Departemen Pengembangan Organisasi Divisi CHR SIG) yang bersedia melakukan wawancara dan diskusi serta dinilai dapat memberikan pendapatnya dan cukup mengerti berkenaan dengan hal yang ingin diwawancarai.

\subsubsection{Waktu, Tempat dan Pengambilan Sampel}

Penelitian ini mengambil tempat disebuah organisasi pelayaran transportasi Samudera Indonesia Group (SIG) Jakarta (Slipi, Tanjung Priok, Kali Baru, dan Kota). Periodepengamatan adalah lebih dari 4 bulan terhitung mulai dari Januari hingga April 2010. SIG sendiri merupakan perusahaan dibidang pelayanan jasa transportasi dan pengiriman barang dengan jalur laut, yang berdiri kurang lebih 64 tahun hingga sekarang, terdiri dari 12 entitas.

Partisipan dalam penelitian ini karena teknik pengumpulan data yang dilakukan adalah wawancara dan FGD maka dinamakan narasumber, yaitu level manajerial dan level non manajerial yang dibagi berdasarkan perwakilan lini bisnis dengan non probability sampling. Tujuan pengambilan sampel bukanlah semata-mata untuk memperoleh representasi populasi untuk dikembangkan menjadi generalisasi induktif melainkan untuk menggali sebanyak mungkin data dan informasi dari sampel informan atau narasumber. Pemilihan narasumber didasarkan pada beberapa kriteria yaitu:

1. Mewakili level karyawan (baik manajerial maupun non manajerial).

2. Mewakili lini bisnisnya. 
3. Memiliki masa kerja minimal 5 tahun untuk level manajerial dan minimal 9 tahun untuk level non manajerial.

4. Mampu berkomunikasi dengan baik.

Dari keempat kriteria tersebut maka dibantu dengan counterpart (Kepala Departemen Pengembangan Organisasi CHR SIG) dipilihlah 8 orang yang di wawancarai dan 10 orang masing-masing kelompok untuk FGD akan tetapi pada kenyataannya yang dapat hadir adalah 7 orang untuk level manajerial dan 5 orang untuk level non manajerial (Lihat Tabel 2 dan 3), selain itu juga dilakukan wawancara mendalam dengan Kepala Divisi CHR, Kepala Departemen Pelatihan dan Pengembangan CHR, dan Supervisor IT CHR.

Data dikumpulkan melalui teknik wawancara mendalam, FGD, dan observasi. Wawancara adalah teknik pengumpulan data yang didasarkan pada percakapan secara intensif dengan suatu tujuan tertentu.

\section{TEMUAN DAN ANALISIS}

Pelaksanaan penelitian kualitatif pada SIG, dilakukan untuk menggali sejauhmana LO di perusahaan melalui penjabaran berdasarkan 5 model LO Marquardt. Pelaksanaan penelitian dilakukan dengan cara FGD dan wawancara yang mendalam dengan para manajer dan karyawan dari empat lini bisnis SIG. Adapun dari hasil penelitian lapangan kualitatif diperoleh temuan-temuan penelitian seperti yang diuraikan berikut ini.

\subsection{Learning}

Dari hasil penelitian lapangan kualitatif diperoleh proposisi-proposisi tentang komponen-komponen yang berhubungan dengan subsistem learning. Secara umum, keinginan untuk belajar dari dalam individu belum merata karena masih terdapat karyawan yang berpandangan bahwa untuk melakukan pembelajaran tidak akan mendapatkan sesuatu yang bermanfaat bagi dirinya, terlebih lagi kegiatan belajar dianggap sebagai kegiatan yang perlu diberikan waktu khusus karena rutinitas pekerjaan menjadi alasan untuk sulit melakukan kegiatan belajar.

Sementara itu dari sisi tipe belajar yang ada di SIG cenderung lebih adaptif (meskipun ada yang antisipatif) dimana jarang sekali dilakukan pola belajar yang sifatnya memprediksi apa yang akan terjadi kedepannya, lebih sebagai follower dan merespons ketika ada masalah, pembelajaran antisipatif ini dilakukan karena pengaruh bidang pekerjaan masing-masing dan juga peraturan yang ada.

Demikian juga dengan keterampilan belajar secara organisasi, kemampuan berpikir sistem secara lebih jelas sehingga dapat belum ditemui di SIG bahasan tersebut ketika IT di salah satu unit bisnis yang seharusnya berperan sebagai supporting function, mengganggap dirinya bukan sebagai bagian dari tim. Ketrampilan lain yakni model mental, terlihat bahwa belajar diasumsikan sebagai kegiatan khusus yang dilakukan didalam ruangan, padahal belajar memiliki makna yang lebih luas daripada itu.

\subsection{Organization}

Dari visi yang ingin menjadi perusahaan terkemuka di Asia, tentunya dituntut untuk senantiasa menggiatkan pembelajaran yang berkelanjutan apabila tidak ingin tertinggal dengan perusahaan lain yang juga semakin berkembang. Begitu pula dengan misi dalam penyediaan pelayanan yang berkualitas, hal yang berkualitas diketahui dari pertukaran informasi, memprediksi apa yang dibutuhkan di masa depan, dan mempelajari masalah yang timbul agar tidak akan terulang pada masa yang akan datang. 
Sementara itu, dari nilai perusahaan, ada beberapa poin yang menghargai kreativitas dan inovasi perseorangan, dari situ dapat ditarik kesimpulan bahwa perusahaan juga ingin membangun semangat belajar dari individu itu sendiri. Untuk strategi, SIG ingin melebarkan sayapnya, melakukan sinergi, dan peningkatan kemampuan, jelas terlihat memang saat ini perusahaan menginginkan baik individu, kelompok, maupun organisasi secara keseluruhan untuk melakukan pembelajaran.

Mengenai struktur, SIG memiliki 4 jenjang hirarki dalam struktur, dan menganut sentralisasi dimana keputusan pengembangan bisnis unit ada di tangan Board of Director. Walaupun demikian, dalam struktur yang ada saat ini pembelajaran lintas divisi dapat terjadi

Untuk aspek budaya jika melihat konteks hubungan budaya dan pembelajaran, perlu dikaji sejauhmana suasana atau iklim di SIG mendukung untuk pembelajaran. Iklim diartikan: bahwa ada pembelajaran dihargai dan diakui, ada kenyamanan (psychological safety) dalam pembelajaran serta komitmen pemimpin untuk menggalakan pembelajaran. Berdasarkan hasil observasi, untuk FGD non manajerial, karyawan enggan untuk menanggapi pertanyaan dari moderator dengan alasan takut jika mereka mengungkapkan pendapat akan berdampak negatif pada diri mereka.

\subsection{People}

Dari hasil wawancara, top management memiliki keinginan untuk membangun LO di SIG. Keinginan tersebut tampak dari adanya ide untuk mendirikan semacam sekolah atau universitas sebagai tempat pembelajaran karyawan SIG serta himbauan untuk mengadakan gathering dalam rangka membagi ilmu.

Upaya mendirikan tempat pembelajaran masih berada pada tahap persiapan awal, yakni menentukan metode pembelajaran, mempersiapkan modul, serta infrastrukturnya. Sedangkan himbauan yang pernah dilontarkan, pada awalnya berjalan, dengan mengundang para Kadiv, Kabag, dalam gathering tentang dana pensiun dan pada kesempatan tersebut, turut hadir para BOD dan Komisaris.

Untuk pemberdayaan karyawan dalam peningkatan kemampuan belajar, dirasakan positif oleh responden. Peran pihak eksternal, yakni konsumen, partner bisnis, tidak begitu dimaksimalkan sebagai upaya untuk meningkatkan pembelajaran.

\subsection{Knowledge}

Untuk pengelolaan pengetahuan di SIG saat ini sudah mulai di kembangkan kedepannya, dan ada pula beberapa kebijakan yang mengatur meskipun sifatnya masih sebatas pelatihan yang rutin dilakukan tiap tahun, seperti kebijakan untuk mengikuti pelatihan dan men-share hasil pelatihan yang didapat dengan cara presentasi kembali, akan tetapi untuk hal yang sifatnya pembelajaran yang berkaitan erat dengan masing-masing bisnis unit tidak jarang dilakukan secara desentralisasi, kegiatan yang berrsifat teknis operasional di berikan wewenang sepenuhnya kepada bisnis unit dan anak perusahaan, terlebih untuk perusahaan yang telah memiliki sertifikasi.

Akan tetapi di lain pihak pemerolehan pengetahuan dari media internet masih sangat terbatas, padahal hal ini cukup penting pula bagi keberlangsungan divisi terkait.

\subsection{Technology}

Pemaparan serta interpretasi yang diperoleh dari FGD dan wawancara menjelaskan bahwa penggunaan teknologi di SIG diperuntukkan untuk komunikasi (dengan adanya penggunaan VOIP), aplikasi yang digunakan di masing-masing unit 
bisnis, dan untuk membantu pekerjaan (email dan akses internet). Selain itu, teknologi dimanfaatkan untuk mengelola pengetahuan, yakni dengan adanya rancangan penyediaan wadah "employee area" bagi karyawan untuk belajar serta mendapatkan informasi tentang perusahaan.

\subsection{Kesenjangan}

Berdasarkan hasil analisa temuan yang telah dilakukan sebelumya, dapat dilihat kesenjangan penerapan LO di SIG berdasarkan lima subsistem LO. Adapun kesenjangannya dapat dilihat pada tabel 2 .

Tabel 2.

Kesenjangan Penerapan LO di SIG

\begin{tabular}{|c|c|c|c|c|}
\hline No. & Subsistem & Metode & Temuan & Kesenjangan \\
\hline$\overline{1}$ & 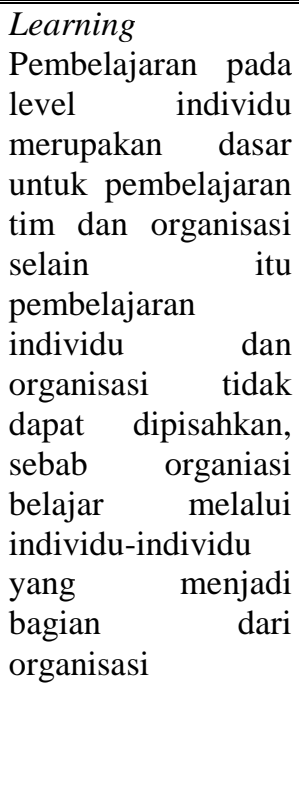 & $\begin{array}{c}\text { Observasi } \\
\text { dan } \\
\text { wawancara }\end{array}$ & 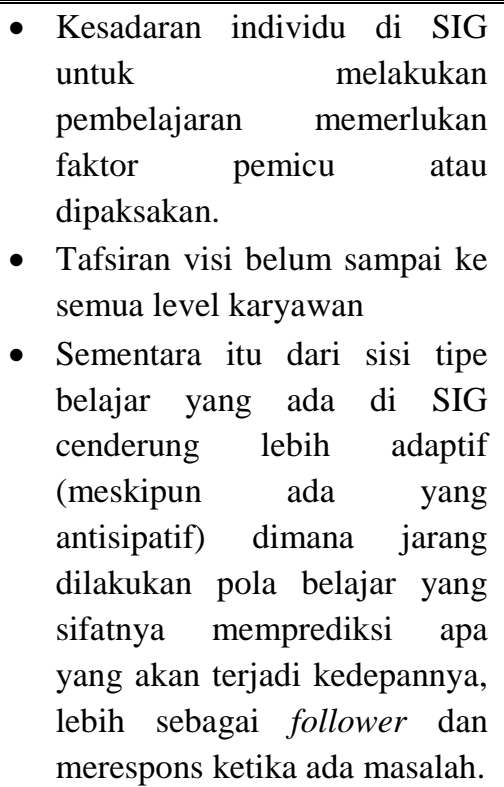 & $\begin{array}{l}\text { Secara keseluruhan dinamika } \\
\text { pembelajaran di SIG belum } \\
\text { merata di semua level } \\
\text { karyawan. } \\
\text { Shared vision belum berjalan } \\
\text { dengan baik, belum semua } \\
\text { level karyawan mengetahui. } \\
\text { Kegiatan sharing dan diskusi } \\
\text { belum diatur secara terstruktur }\end{array}$ \\
\hline$\overline{2}$ & $\begin{array}{l}\text { Organization } \\
\text { Untuk menjadikan } \\
\text { sebagai organisasi } \\
\text { pembelajar, } \\
\text { diperlukan struktur } \\
\text { datar dan flexible } \\
\text { sehingga dapat } \\
\text { memaksimalkan } \\
\text { lintas arus } \\
\text { informasi. Visi, } \\
\text { misi, nilai-nilai, } \\
\text { strategi dan budaya } \\
\text { yang mendukung } \\
\text { pembelajaran }\end{array}$ & $\begin{array}{c}\text { Observasi } \\
\text { dan } \\
\text { wawancara }\end{array}$ & 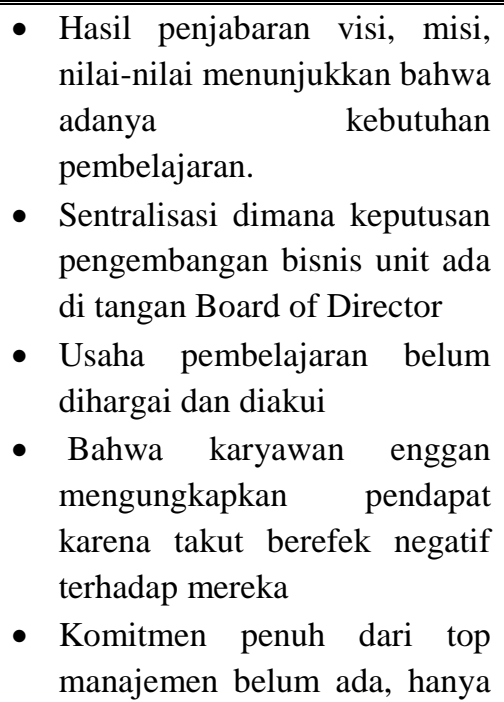 & $\begin{array}{l}\text { Iklim belajar } \\
\text { mendukung selum } \\
\text { pembelajaran belum dihargai } \\
\text { dan diakui, selain itu untuk } \\
\text { kenyamanan (psychological } \\
\text { safety) ditemukan bahwa } \\
\text { karyawan enggan } \\
\text { mengungkapkan pendapat } \\
\text { karena takut berefek negatif } \\
\text { terhadap mereka } \\
\text { Belum ada komitmen untuk } \\
\text { pembelajaran dari top } \\
\text { manajemen }\end{array}$ \\
\hline
\end{tabular}




\begin{tabular}{||l||l|l||l|}
\hline \hline & terbatas pada dukungan \\
verbal. & $\begin{array}{l}\text { Untuk pengembangan unit } \\
\text { bisnis masih birokratis, } \\
\text { usulan pengembangan } \\
\text { diputuskan sepenuhnya oleh } \\
\text { BOD }\end{array}$ \\
& & & \\
\hline
\end{tabular}

\section{RANCANGAN IMPLEMENTASI MEMBANGUN LO DI SIG TAHUN 2011-2013}

Dari hasil analisa yang dilakukan pada Bab IV, nampak bahwa upaya membangun LO di SIG sudah mulai terlihat walaupun masih pada tahap embrio, hal tersebut tercermin dari:

1. Pemimpin

- Inisiatif untuk membudayakan sharing knowledge dari top management.

- Ada upaya pemimpin untuk membimbing bawahan melalui cara kerja tandem.

2. Infrastruktur Teknologi

- Perencanaan e-learning yang saat ini masih dalah proses penyempurnaan, elearning ini nantinya bertujuan untuk memudahkan akses belajar seluruh karyawan.

- Ada inisiatif yang dilakukan HRIS untuk membuat informasi, kebijakan serta Standard Of Procedure dalam bentuk computer based, sehingga memudahkan karyawan dalam mengakses.

3. Visi, misi, nilai-nilai dan strategi mencerminkan kebutuhan pembelajaran sehingga mendukung organisasi dalam membangun LO.

4. Pada beberapa bisnis unit yang memiliki sertifikasi ISO dan OSAS sudah menerapkan pembelajaran, seperti ada kegiatan diskusi rutin serta English day. Hanya saja intensitasnya kurang dan belum merata di SIG.

5. Rencana pengembangan personal development plan sebagai upaya feedback atas hasil asesment.

Berdasarkan kondisi yang ditemui di SIG saat ini. Akan dirancang usulan rancangan implementasi membangun LO di SIG (2011-2013) yang dapat dilihat pada tabel 3. Untuk menjalankan rancangan implementasi, diperlukan time line. Time line dapat dilihat pada tabel 4 .

Tabel 3.

Rancangan implementasi membangun LO di SIG (2011-2013)

\begin{tabular}{|c|c|c|c|}
\hline Subsistem & Kesenjangan & $\begin{array}{c}\text { Rancangan } \\
\text { Penyempurnaan }\end{array}$ & Implementasi \\
\hline Learning & $\begin{array}{l}\text { Secara keseluruhan } \\
\text { dinamika pembelajaran } \\
\text { di SIG belum merata di } \\
\text { semua level karyawan. } \\
\text { Shared vision belum } \\
\text { berjalan dengan baik, } \\
\text { belum semua level }\end{array}$ & 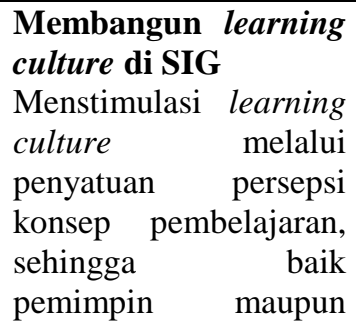 & $\begin{array}{l}\text { 1. Membentuk tim khusus } \\
\text { yang bertanggung jawab } \\
\text { untuk program LO } \\
\text { 2. Menunjuk role model } \\
\text { dalam hal pembelajaran } \\
\text { 3. Memastikan topik LO } \\
\text { masuk dalam }\end{array}$ \\
\hline
\end{tabular}




\begin{tabular}{|c|c|c|c|}
\hline & $\begin{array}{l}\text { karyawan mengetahui. } \\
\text { Terdapat model mental } \\
\text { yang menghalangi } \\
\text { dalam melakukan } \\
\text { pembelajaran } \\
\text { Belum menggunakan } \\
\text { cara berpikir sistemik, } \\
\text { yang terjadi adalah silo } \\
\text { mentality } \\
\text { Kegiatan sharing dan } \\
\text { diskusi belum diatur } \\
\text { secara terstruktur }\end{array}$ & $\begin{array}{l}\text { karyawan memiliki } \\
\text { pengertian yang sama. } \\
\text { Selain itu peran } \\
\text { pemimpin penting pada } \\
\text { tahap awal untuk } \\
\text { mendukung } \\
\text { terbentuknya learning } \\
\text { culture. }\end{array}$ & 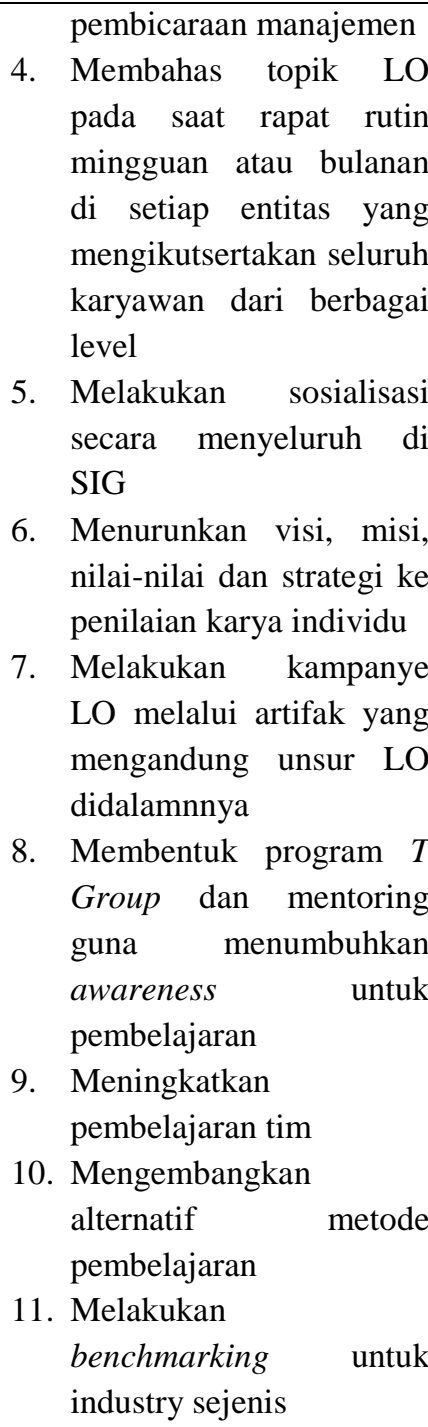 \\
\hline Organization & $\begin{array}{l}\text { Iklim belajar belum } \\
\text { mendukung sebab } \\
\text { usaha pembelajaran } \\
\text { belum dihargai dan } \\
\text { diakui, selain itu } \\
\text { untuk kenyamanan } \\
\text { (psychological safety) } \\
\text { ditemukan bahwa } \\
\text { karyawan enggan } \\
\text { mengungkapkan } \\
\text { pendapat karena takut }\end{array}$ & 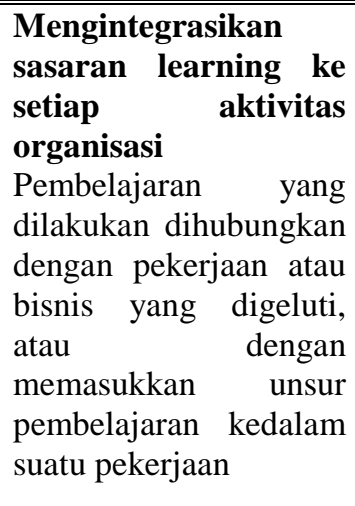 & $\begin{array}{l}\text { 1. } \begin{array}{l}\text { Melakukan review } \\
\text { struktur organisasi } \\
\text { untuuk melihat apakah } \\
\text { ada struktur yang } \\
\text { sifatnya terlalu birokratif } \\
\text { 2. Merancang work flow } \\
\text { suatu kegiatan pekerjaan } \\
\text { 3. Membentuk sebuah } \\
\text { group sharing sesuai } \\
\text { fungsi }\end{array} \\
\text { 4. Mengembangkan sistem }\end{array}$ \\
\hline
\end{tabular}




\begin{tabular}{|c|c|c|c|}
\hline & $\begin{array}{l}\text { berefek negatif } \\
\text { terhadap mereka } \\
\text { Belum ada komitmen } \\
\text { untuk pembelajaran } \\
\text { dari top manajemen } \\
\text { Untuk pengembangan } \\
\text { unit bisnis masih } \\
\text { birokratis, usulan } \\
\text { pengembangan } \\
\text { diputuskan } \\
\text { sepenuhnya oleh BOD }\end{array}$ & & 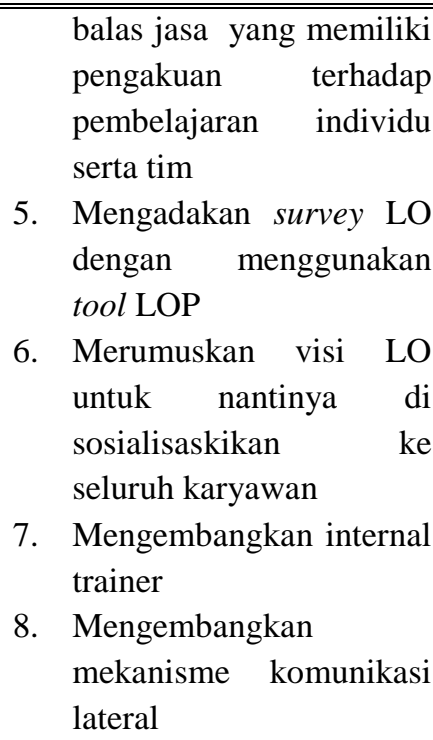 \\
\hline \multirow[t]{3}{*}{ People } & $\begin{array}{l}\text { Belum ada koordinasi } \\
\text { untuk forum diskusi } \\
\text { sehingga forum } \\
\text { selanjutnya tidak } \\
\text { berjalan } \\
\text { Inisiatif pemimpin } \\
\text { untuk melanjutkan } \\
\text { kegiatan diskusi tidak } \\
\text { ada } \\
\text { Karyawan belum dapat } \\
\text { memanfaatkan waktu } \\
\text { yang untuk } \\
\text { pembelajaran }\end{array}$ & $\begin{array}{lr}\begin{array}{l}\text { Melakukan } \\
\text { koordinasi } \\
\text { fungsi }\end{array} \\
\text { pembelajaran }\end{array}$ & 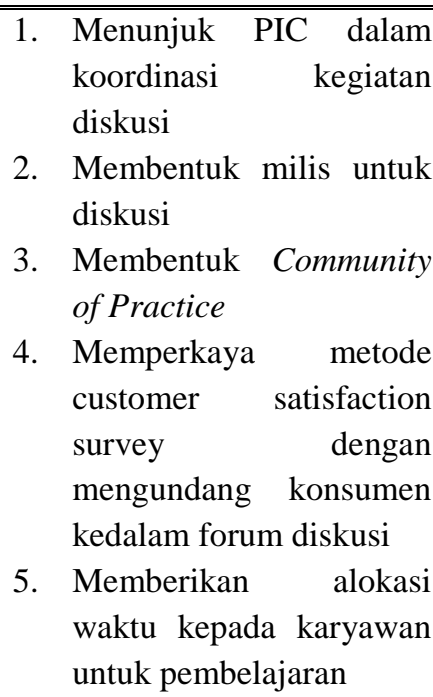 \\
\hline & $\begin{array}{l}\text { Kerjasama dengan } \\
\text { pihak eksternal } \\
\text { (vendor, pelanggan dan } \\
\text { supplier) belum } \\
\text { merata terutama untuk } \\
\text { memanfaatkan } \\
\text { penggalian informasi } \\
\text { dan pengetahuan. }\end{array}$ & $\begin{array}{l}\text { Mengembangkan } \\
\text { mekanisme } \\
\text { penyertaan pihak } \\
\text { eksternal dalam } \\
\text { upaya pembelajaran } \\
\text { Penyertaan peran pihak } \\
\text { eksternal untuk } \\
\text { memperoleh informasi } \\
\text { dan pengetahuan. } \\
\end{array}$ & $\begin{array}{ll}\text { 1. } & \text { Mengundang expert } \\
\text { dalam industri untuk } \\
\text { sharing }\end{array}$ \\
\hline & $\begin{array}{l}\text { Sedangkan untuk } \\
\text { sistem SDM } \\
\text { kesenjangan yang } \\
\text { ditemui adalah: } \\
\text { 1. Pelatihan dan }\end{array}$ & \begin{tabular}{lr}
\multicolumn{2}{l}{ Menyempurnakan } \\
Pelatihan & dan \\
Pengembangan & \\
Pelatihan r yang \\
melibatkan & proses \\
\end{tabular} & $\begin{array}{llr}\text { 1. } & \text { Pemberian kesempatan } \\
& \text { training kepada gol 1-4 } \\
\text { 2. } & \text { Membakukan } \\
& \text { rekapitulasi }\end{array}$ \\
\hline
\end{tabular}




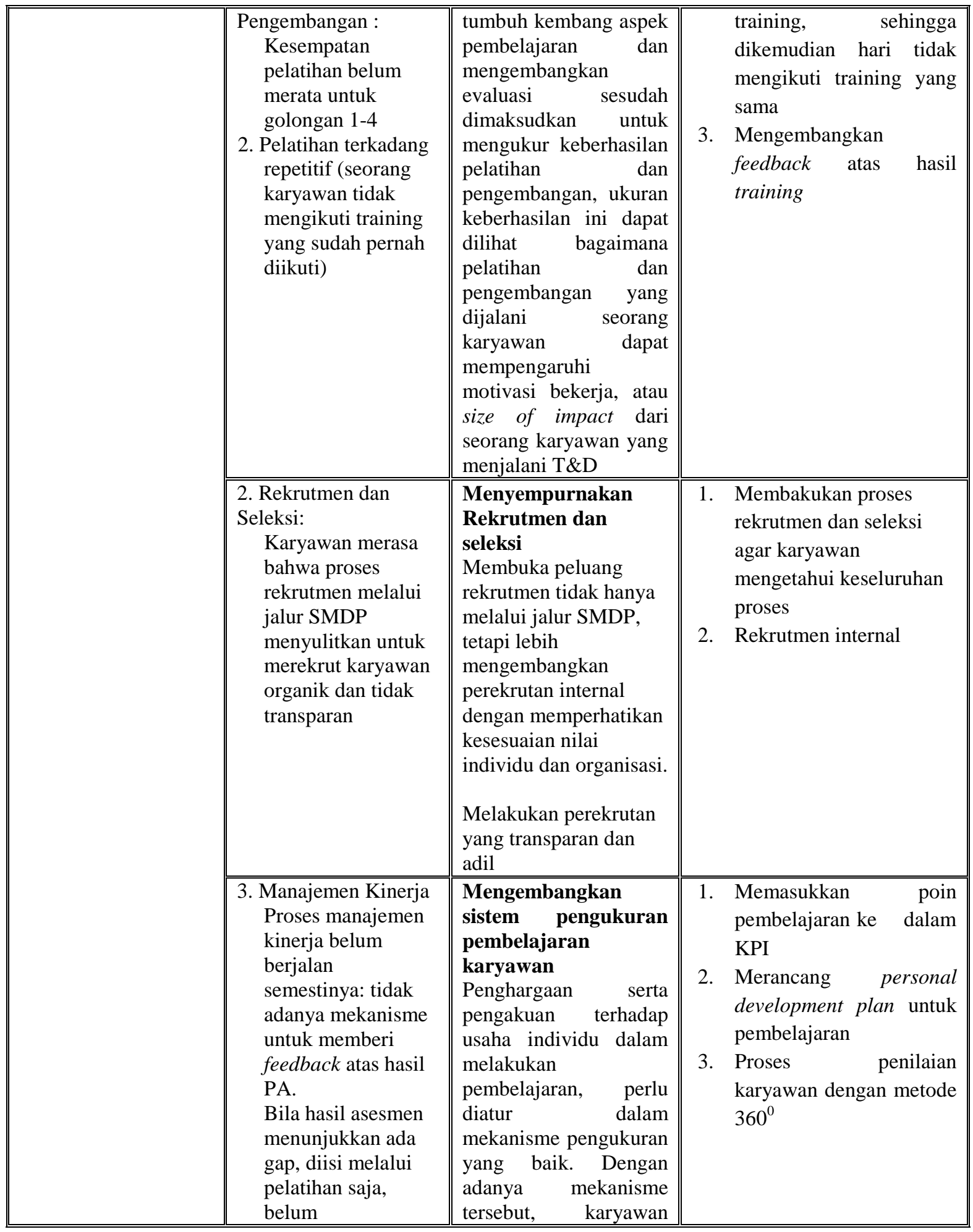




\begin{tabular}{|c|c|c|c|}
\hline & $\begin{array}{l}\text { dikembangkan cara } \\
\text { lain dalam mengisi } \\
\text { gap }\end{array}$ & $\begin{array}{l}\text { merasa usaha yang } \\
\text { dilakukannya dihargai } \\
\text { organisasi } \\
\text { Melakukan integrasi } \\
\text { vertikal, dan integrasi } \\
\text { horizontal } \\
\text { Yakni dimana visi, } \\
\text { misi, nilai serta } \\
\text { obyektif perusahaan } \\
\text { diturunkan sampai } \\
\text { tataran individu dan } \\
\text { secara horizontal hasil } \\
\text { penilaian dan pelaksaan } \\
\text { diturunkan ke setiap } \\
\text { fungsi SDM }\end{array}$ & \\
\hline & $\begin{array}{l}\text { 4. Balas jasa } \\
\text { Dasar pemberian } \\
\text { reward adalah hasil } \\
\text { PA. pemberian } \\
\text { reward untuk } \\
\text { upaya pembelajaran } \\
\text { belum ada }\end{array}$ & $\begin{array}{l}\text { Menghargai upaya } \\
\text { pembelajaran } \\
\text { karyawan } \\
\text { Pemberian balas jasa } \\
\text { lebih adil, dengan } \\
\text { membenahi sistem } \\
\text { penilaian kerja dimana } \\
\text { didalamnya terkandung } \\
\text { aspek-apek } \\
\text { pembelajaran yang } \\
\text { dapat menjadi tolok } \\
\text { ukur dalam pemberian } \\
\text { insentif . Dan tidak } \\
\text { hanya reward berupa } \\
\text { materi, namun perlu } \\
\text { mengembangkan } \\
\text { mekanisme reward } \\
\text { dimana karyawan } \\
\text { merasa diperhitungkan } \\
\text { dan dihargai oleh } \\
\text { organisasi }\end{array}$ & 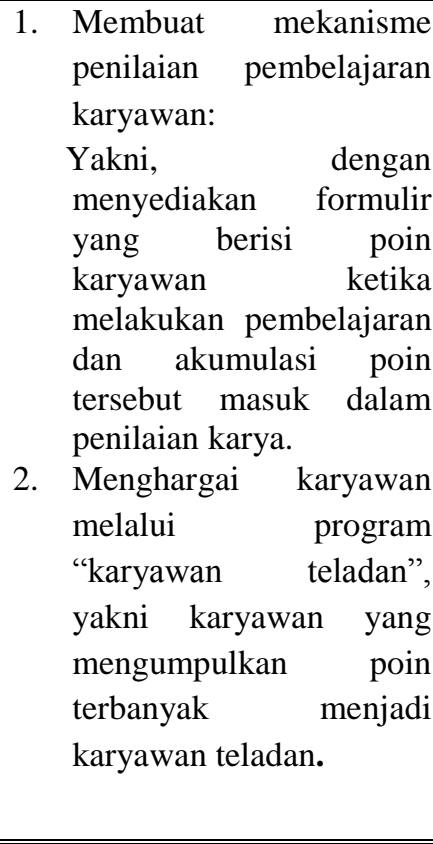 \\
\hline Knowledge & $\begin{array}{l}\text { Keseluruhan proses } \\
\text { transisi pengetahuan } \\
\text { belum berjalan secara } \\
\text { terstruktur. Organisasi } \\
\text { belum melakukan } \\
\text { upaya proses akuisisi } \\
\text { yakni dengan cara } \\
\text { memetakan } \\
\text { pengetahuan } \\
\text { karyawan. } \\
\end{array}$ & $\begin{array}{l}\text { Mengembangkan KM } \\
\text { di SIG melalui } \\
\text { Perancangan untuk } \\
\text { melakukan pemetaan } \\
\text { seluruh pengetahuan } \\
\text { baik tacit dan explicit } \\
\text { yang ada di organisasi. }\end{array}$ & 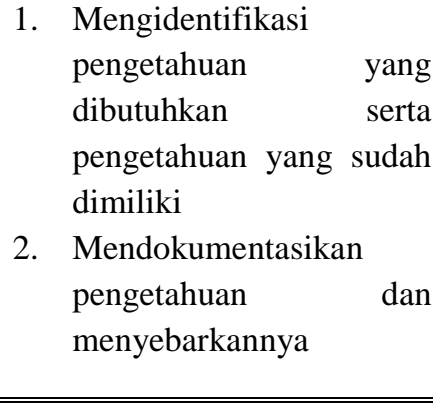 \\
\hline Technology & $\begin{array}{l}\text { Pemanfaatan teknologi } \\
\text { untuk membantu }\end{array}$ & $\begin{array}{l}\text { Membangun dan } \\
\text { mengembangkan }\end{array}$ & $\begin{array}{l}\text { 1. Memanfaatkan teknologi } \\
\text { sebagai sarana diskusi }\end{array}$ \\
\hline
\end{tabular}




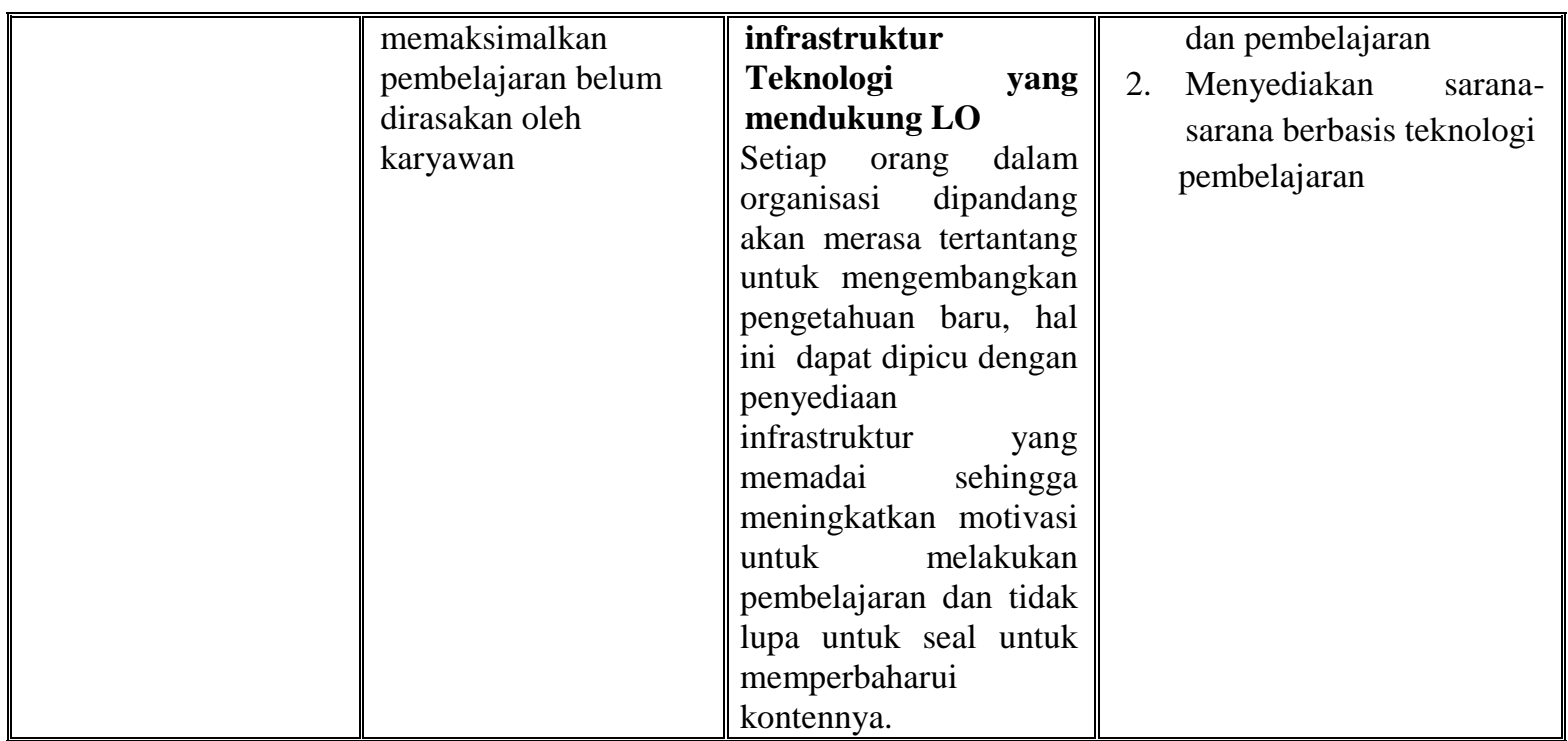

Tabel 4.

Time Line rancangan Implementasi

\begin{tabular}{|c|c|c|c|c|c|c|c|c|c|c|c|c|}
\hline \multirow[t]{3}{*}{ No } & \multirow[t]{3}{*}{ Kegiatan } & \multirow[t]{3}{*}{ PIC } & \multicolumn{9}{|c|}{$\begin{array}{l}\text { Waktu } \\
\end{array}$} & \multirow[t]{3}{*}{ Output } \\
\hline & & & \multicolumn{3}{|c|}{2011} & \multicolumn{3}{|c|}{2012} & \multicolumn{3}{|c|}{2013} & \\
\hline & & & $\overline{C \text { C1 }}$ & $\overline{\mathrm{C2} 2}$ & C3 & C1 & $\overline{\mathrm{C} 2}$ & $\overline{c \text { C3 }}$ & C1 & $\overline{\mathrm{C} 2}$ & $\overline{\mathrm{C} 3}$ & \\
\hline $\bar{~} 1$ & $\begin{array}{l}\text { Merancang rencana } \\
\text { kerja membangun } \\
\text { LO }\end{array}$ & $\begin{array}{c}\text { Top Manajemen, } \\
\text { CHR }\end{array}$ & & & & & & & & & & $\begin{array}{l}\text { Rencana } \\
\text { kerja } \\
\text { membangun } \\
\text { LO beserta } \\
\text { blueprint-nya }\end{array}$ \\
\hline 2 & $\begin{array}{l}\text { Melakukan program } \\
\text { sosialisasi untuk } \\
\text { membangun LO }\end{array}$ & $\begin{array}{c}\text { Top Manajemen, } \\
\text { CHR, seluruh } \\
\text { karyawan }\end{array}$ & & & & & & & & & & $\begin{array}{l}\text { Pemerataan } \\
\text { pemahaman } \\
\text { tentang LO }\end{array}$ \\
\hline 3 & $\begin{array}{l}\text { Membuat kebijakan } \\
\text { yang berkaitan } \\
\text { dengan LO }\end{array}$ & $\begin{array}{c}\text { CHR, Karyawan } \\
\text { manajerial, dan } \\
\text { divisi HR } \\
\text { dimasing-masing } \\
\text { bisnis unit } \\
\end{array}$ & & & & & & & & & & Kebijakan \\
\hline 4 & $\begin{array}{l}\text { Membentuk wadah } \\
\text { untuk bertukar } \\
\text { pikiran }\end{array}$ & $\begin{array}{c}\text { CHR dan seluruh } \\
\text { karyawan }\end{array}$ & & & & & & & & & & $\begin{array}{l}\text { Forum } \\
\text { diskusi yang } \\
\text { berkelanjutan } \\
\end{array}$ \\
\hline$\overline{5}$ & $\begin{array}{l}\text { Membangun sarana } \\
\text { dan infrastruktur } \\
\text { yang mendukung } \\
\text { terciptanya LO }\end{array}$ & $\begin{array}{c}\text { CHR dan seluruh } \\
\text { karyawan }\end{array}$ & & & & & & & & & & $\begin{array}{l}\text { Sarana dan } \\
\text { infrastruktur } \\
\text { LO }\end{array}$ \\
\hline 6 & Evaluasi & $\begin{array}{c}\text { CHR dan seluruh } \\
\text { karyawan }\end{array}$ & & & & & & & & & & $\begin{array}{l}\text { Hasil } \\
\text { evaluasi }\end{array}$ \\
\hline
\end{tabular}




\section{.VI KESIMPULAN DAN SARAN}

Secara garis besar Learning Organization di SIG belum berjalan secara optimal, meskipun benih-benih yang mendukung pembelajaran sudah mulai ditumbuhkan, baik dari visi, misi, nilai, dan strategi.Tidak Pembangunan sarana dan infrastruktur tidak akan berarti, bila kesadaran karyawan untuk melakukan pembelajaran masih rendah. Oleh sebab itu perusahaan perlu melakukan usaha-usaha yang berkesinambungan, sistematis, dan menyeluruh guna menumbuhkan komitmen dari seluruh karyawan. 
Membangun Learning Organization ... (Anglena D. O. dan Yanet M)

\section{DAFTAR PUSTAKA}

Awbrey, S., (n.d) Examining the relationship between Learning organization dimensions and change adaption, innovation as well as organizational performance. Diakses pada tanggal 6 Mei 2010.

Marquardt, Michael J. 2002. Building the Learning Organization. California: Davies Black Publishing, Inc

Park, J., The Learning Organization Model across Vocational and Academic Teacher Groups", 2006. Diakses pada tanggal 23 Juni 2010.

Senge, P. 1990. The Fifth Discipline: The Art and Practice of The Learning Organization". New York: Doubleday. 